\title{
OAT HULLS TREATED WITH ALKALINE HYDROGEN PEROXIDE ASSOCIATED WITH EXTRUSION AS FIBER SOURCE IN COOKIES ${ }^{1}$
}

\author{
Melícia Cintia GALDEANO2,*, Maria Victória Eiras GROSSMANN 3 ,*
}

\begin{abstract}
SUMMARY
Cookies were prepared with the replacement of $20 \%$ of wheat flour by chemically (alkaline hydrogen peroxide) and physically (extrusion) treated oat hulls, with the objective to investigate the possibility of use of this modified material. Cookies elaborated with the untreated hulls were used as control. Cookies were evaluated for their physical (spread ratio, specific volume and color) and sensory characteristics, and no difference was detected $(\mathrm{p} \leq 0.05)$ among the cookies in relation to the physical properties. Triangule test, used to verify difference $(\mathrm{p} \leq 0.05)$ among treated and untreated cookies, confirmed the efficiency of the treatment in sensory level. The acceptance level of cookies with treated fiber was evaluated by potential consumers of the product, obtaining $91 \%$ acceptance. The cookies presented $10.6 \mathrm{~g}$ of dietary fiber per $100 \mathrm{~g}$ of product.

Keywords: modified oat hulls, sensory analysis, dietary fiber.
\end{abstract}

\section{RESUMO}

CASCA DE AVEIA TRATADA COM PERÓXIDO DE HIDROGÊNIO ALCALINO ASSOCIADO À EXTRUSÃO COMO FONTE DE FIBRAS EM BISCOITOS COOKIES. Biscoitos cookies foram preparados com $20 \%$ da farinha de trigo substituída por casca de aveia tratada química (peróxido de hidrogênio alcalino) e fisicamente (extrusão), com o objetivo de investigar a possibilidade de aproveitamento desta matéria-prima modificada. Biscoitos elaborados com o mesmo teor de casca de aveia nativa foram usados como controle. Os biscoitos foram avaliados quanto as suas características físicas (expansão, volume específico e cor) e sensoriais, sendo que não foi detectada diferença $(\mathrm{p} \leq 0,05)$ em relação às propriedades físicas. O teste triangular, usado para verificar diferença significativa ( $\mathrm{p} \leq 0,05)$, em nível global, entre as amostras tratada e nativa, confirmou a eficiência do tratamento em nível sensorial. O grau de aceitação dos biscoitos com fibra tratada foi avaliado por consumidores potenciais do produto, obtendo-se aceitação de $91 \%$. Os biscoitos apresentaram 10,6 g de fibra alimentar por $100 \mathrm{~g}$ de produto.

Palavras-chave: casca de aveia modificada, análise sensorial, fibra alimentar.

\section{1 - INTRODUCTION}

So far, food industries and food researchers are involved in nutritional aspects of food and in the improvement of taste, color, reology and physical and chemical properties of food, intending them into a more attractive product for the consumption. Recently, a worldwide interest on foods that have substances with biological function that can be involved in preventing diseases and promoting health has been observed [12]. Therefore, food industries have been launching products with functional components. Foods containing these substances are denominated functional foods, and dietary fiber is one of the ingredients applied in them.

Several studies have demonstrated the interest in incorporating cereals fibers in breads $[12,18]$ and cookies $[3,4,10,13]$.

\footnotetext{
${ }^{1}$ Recebido para publicação em 9/2/2005. Aceito para publicação em 23/1/2006 (001479)

${ }^{2}$ Famacêutica-bioquímica, com mestrado em Ciência e Tecnologia de Alimentos e doutoranda em Ciência e Tecnologia de Alimentos Rua Espírito Santo, 87, apto. 703

CEP 86010-510 - Londrina (PR)

${ }^{3}$ Graduação em Química e doutora em Tecnologia de Alimentos Rodovia Celso Garcia Cid, s/n $n^{\circ}$ Caixa Postal 6001

CEP 86050-901 - Londrina (PR)

*A quem a correspondência deve ser enviada
}

Cookies have a great variety of formulations and the advantage of presenting good acceptance, particularly among children, besides maintaining their qualities for a long time [17].

The criterion adopted for incorporation of fibers in food systems is the maintenance of sensory characteristics of product, because the success of incorporation still depends on consumers acceptability [14].

Traditionally, oat hulls, a byproduct of oat groat milling, are discarded during processing, becoming an environmental pollutant. Due to its high fiber content (about 90\%), higher than wheat $(47 \%)$ or corn bran $(62 \%)$, it becomes an important ingredient that can be incorporated in several food formulations [16]. However, unfortunately, gritty texture and degradation of dough properties are frequently associated with their presence, probably, because these materials tend to hydrate only superficially, reducing the particles swelling in the dough matrix [7].

The physical properties of fiber can be improved by physicochemical treatments, which solubilize a portion of the lignin, originally present in the lignocellulosic matrix, and reduces cellulose crystallinity producing a material with a more open internal structure, causing an increase in the water retention capacity and swelling of the fiber, getting better, therefore, sensory characteristics of the product [7]. 
INGLETT [8] processed agricultural byproducts in multistep shear process and long time of digestion ( up to $72 \mathrm{~h}$ ) with alkaline hydrogen peroxide, obtaining products with pronounced modifications in their hydration properties. LARREA et al. [9] pretreated rice hulls with alkaline solution of hydrogen peroxide followed by extrusion obtaining also an increase in the fiber hydration properties.

However, these procedures besides generate great volume of effluents, result in high cost and long time of reaction and the simplified processes are becoming more and more interesting for modification of food products. Therefore, an only one-step process was developed, with short time of reaction and without generation of residues, an oat hulls fiber with higher hydration capa-city than raw hulls [6].

Many applications can be proposed for this modified oat hulls. The objective of this paper was to investigate the potential use of this modified material in the production of cookies through valuation of their physical (spread ratio, specific volume and color) and sensory characteristics.

\section{2 - MATERIAL AND METHODS}

\section{1 - Material}

Raw oat hulls (4.3\% protein, $3.5 \%$ ash, $1.8 \%$ lipid, $88 \%$ total dietary fiber, $\mathrm{L}^{*}=67.52$ and $\left.\mathrm{pH} 5.69\right)$ and modified oat hulls produced as described ahead $(6.7 \%$ protein, $2.8 \%$ ash, $0.6 \%$ lipid, $80 \%$ total dietary fiber, $\mathrm{L}^{*}=69.87$ and $\mathrm{pH}$ 8.56 ) were used at $20 \%$ wheat flour substitution for production of cookies. Other ingredients (wheat flour, shortening, sugar, salt and sodium bicarbonate) of the formulation were bought from a local market.

\section{2 - Methods}

\subsection{1 - Treatment of the hulls}

The methodology described by GALDEANO \& GROSSMANN [6] was applied. The hulls were conditioned with the necessary water to attain $32 \%$ moisture and the amount of sodium hydroxide (dissolved in this water) to attain $\mathrm{pH}$ 11.5. Material was placed in sealed polyethylene bags and allowed to equilibrate for $24 \mathrm{~h}$ to the refrigerator. Hydrogen peroxide $(7 \%)$ was sprinkled in the sample. Material placed in sealed polyethylene bags returned to the refrigerator for 1 hour and then extruded. The process was carried out in a single-screw extruder (Cerealtec CT-L15, Brazil) at $90^{\circ} \mathrm{C}$. The extruder has a barrel of $420 \mathrm{~mm}$ in length, $19.4 \mathrm{~mm}$ in diameter, three heating zones, 1:2 compression ratio screw and $8 \mathrm{~mm}$ die diameter. Screw speed (150 rpm) and feeding rate (70 g/min) were maintained constant. Samples were collected, dried at $50^{\circ} \mathrm{C}$ in a forced-air convection oven to $13 \%$ moisture, ground and stored in sealed polyethylene bags at room temperature until use.

\subsection{2 - Cookie preparation}

Cookies were produced according to AACC macromethod 10-50D [ 1 ] adapted for fiber supplementation. The formulation was: shortening, $64 \mathrm{~g}$; sugar, $130 \mathrm{~g}$; salt, $2.1 \mathrm{~g}$; sodium bicarbonate, $2.5 \mathrm{~g}$; dextrose solution ( $8.9 \mathrm{~g}$ dextrose in $150 \mathrm{~mL}$ water), $33 \mathrm{~mL}$; water, $48 \mathrm{~mL}$; wheat flour, 180 $\mathrm{g}$ and oat hulls, $45 \mathrm{~g}$. Preliminary tests were conducted to define the level of substitution of flour by fiber and the amount of water of formulation. So, it was detected that it was possible to substitute $20 \%$ of the flour triplicating the water of the formulation.

The dough was processed in a domestic mixer. Firstly, the shortening, sugar, salt and chemical ferment were mixed on low speed for three min. Then, the water and dextrose solution was added, mixed on low speed for one minute and on medium speed for two minutes. After addition of wheat flour and fiber, the dough was mixed on low speed for two minutes. The dough was divided into small portions, rolled and cut (cookie cutter), with rigorous control of diameter and thickness. The cookies were baked for $15 \mathrm{~min}$ at $200 \pm 2^{\circ} \mathrm{C}$. After baking, the cookies were cooled to room temperature, then stored in sealed polyethylene bags until use.

\subsection{3 - Physicochemical analyses of cookies}

Moisture (44-15A), protein (46-13), ash (08-01), lipids (30-26), total dietary fiber and soluble and insoluble fractions (32-07) were determined according to AACC methods [1]. All determinations were run in triplicate.

Diameter, thickness and spread ratio of cookies with raw and treated fibers were calculated according to AACC macromethod 10-50D [1]. Spread ratio was determined by dividing diameter by thickness and specific volume as in LUE et al. [11]. Color was determined by Photovolt (model 575), using filter $\mathrm{Y}$ and illuminant $\mathrm{C}$ (6774K), with white calibration standard for $75 \%$ reflectance and black for $0 \%$ reflectance. Determinations were run in triplicate and results were converted to corresponding CIELAB values and expressed as brightness $\left(\mathrm{L}^{*}\right)$. Statistical analyses were performed using the Statistica software (Statsoft, Oklahoma). Data were analyzed by Tukey's test at the 0.05 level of probability.

The $\mathrm{pH}$ was measured according to AACC method 02-52 [1].

\subsection{4 - Sensory evaluation}

\subsubsection{1 - Difference test}

The triangle test with twenty trained taste panelists was used to detect differences between treated and untreated samples and to confirm or not the efficiency of treatment in sensorial level [5]. The results were analyzed by the significance table of the test. If a difference was discerned, acceptance test was necessary to verify the general acceptability of the product by consumers. 


\subsubsection{2 - Acceptance test}

The acceptability of cookie with modified oat hulls was evaluated by a hundred potentials consumers of the product. The test was carried out in a local supermarket. The panelists, using a nine points structured hedonic scale, expressed the degree of liking of the product, being the degree 1 attributed to displease very much and 9 to like very much [5]. The results were obtained by calculation of overall mean and the acceptance index was determined as acceptance percentage considering $100 \%$ the score 9 .

\section{3 - RESULTS AND DISCUSSION}

\section{1 - Chemical composition of cookies}

The chemical composition (\%, dwb) of cookies produced with modified oat hulls is presented in the Table 1. In the same Table, the product produced in this paper can be compared to one commercial product with fiber.

TABLE 1 - Chemical composition (\%, dwb) of cookies with modified oat hulls and commercial cookie with fiber

\begin{tabular}{|c|c|c|}
\hline & Cookies with oat hulls & Commercial cookie $^{a}$ \\
\hline Protein $(\mathrm{N} \times 6,25)$ & 5.21 & 7,30 \\
\hline Ash & 3.15 & 3,90 \\
\hline Lipids & 15.65 & 20,3 \\
\hline $\mathrm{TDF}^{\mathrm{b}}$ & 10.56 & 6,30 \\
\hline Soluble dietary fiber & 0.10 & - \\
\hline Insoluble dietary fiber & 10.46 & - \\
\hline Nitrogen-free extract ${ }^{c}$ & 65.43 & 62,20 \\
\hline
\end{tabular}

The substitution of $20 \%$ wheat flour by modified oat hulls reached about $1.1 \mathrm{~g}$ dietary fibers per $10 \mathrm{~g}$ of cookie (equivalent to one cookie), while the fiber content in commercial cookie is about $3 / 5$ of this.

According to Brazilian legislation, a solid product is considered as a high fiber source if it presents at least $6 \%$ fiber [2]. Therefore, the cookies produced in this study can be considered a high-fiber product.

SILVA et al. [17] reported that the consumption from 3 to $45 \mathrm{~g}$ of insoluble fiber is enough for prevention of constipation symptoms or diverticular disease. Then, the daily consumption of three cookies could contribute to soothe these disturbances. As each cookie (approximately $10 \mathrm{~g}$ ) presents about $1.06 \%$ dietary fiber, 10 cookies would correspond to $43 \%$ of recommended daily consumption (25 g).

\section{2 - Physical characterization of cookies}

The physical properties of cookies with treated and untreated fibers presented nonsignificant difference $(\mathrm{p} \leq 0.05)$ (Table 2). The spread and specific volume values correspond to previous studies that also obtained cookies with $20 \%$ of flour substituted by different fiber sources [4, 15].
TABLE 2 - Physical characteristics of cookies with oat hulls

\begin{tabular}{lcc}
\hline Physical parameters & \multicolumn{2}{c}{ Cookie } \\
& Treated Oat Hulls & Untreated Oat Hulls \\
\hline Diameter $(\mathrm{mm})$ & $58.2^{\mathrm{a}}$ & $60.2^{\mathrm{a}}$ \\
Thickness $(\mathrm{mm})$ & $7.7^{\mathrm{a}}$ & $8.5^{\mathrm{a}}$ \\
Spread ratio & $7.75^{\mathrm{a}}$ & $7.18^{\mathrm{a}}$ \\
Specific volume $(\mathrm{mL} / \mathrm{g})$ & $2.22^{\mathrm{a}}$ & $1.98^{\mathrm{a}}$ \\
Color $\left(\mathrm{L}^{*}\right)$ & $63.10^{\mathrm{a}}$ & $62.90^{\mathrm{a}}$ \\
\hline
\end{tabular}

Means, in the same line, followed by the same letter are not significantly different (Tukey's test, $\mathrm{p} \leq 0.05$ ).

ARTZ et al. [3] produced cookies with $15 \%$ of substitution of flour with extruded and nonextruded corn fiber and also verified that there was not significant difference regarding to cookie spread.

The small difference in the color between the untreated $\left(\mathrm{L}^{*}=67.52\right)$ and modified hulls $\left(\mathrm{L}^{*}=69.87\right)$ was not enough to impart significant difference between cookies in this parameter.

\section{3 - Cookies pH}

Cookies pHs were 8.92 and 9.12 for cookies with raw fiber and modified fiber, respectively. This confirms that, in spite of $\mathrm{pH}$ difference between untreated and treated oat hulls (pH 5.69 and 8.56, respectively), there was not a high modification of the final $\mathrm{pH}$ of the product, since these ingredients were incorporated at low levels in the formulation.

\section{4 - Sensorial analysis}

\subsection{1 - Triangle tests}

Significant differences ( $\mathrm{p} \leq 0.05)$ between cookies produced with treated and untreated fibers were detected. The differences found, according to panel, locates mainly to the lack of gritty texture on cookies prepared with treated oat hulls, indicating that the treatment was effective. The panel indicated preference for the cookie with treated fiber.

It is important to point out that the modification of gritty sensation of treated hulls was reached even without great increases on hydration properties [6] indicating that the destructuring of the fiber was enough to make this material more palatable than untreated oat hulls.

Artz et al. [3], using the same test for cookies produced with extruded and nonextruded fibers, verified that there was no difference between samples, confirming the need of association of physical and chemical treatments to promote sensible modifications.

\subsection{2 - Acceptance test}

When a new product is developed, one of the main points in the evaluation is its acceptability, in order to predict its behavior in the consumer market [14]. Sensory analysis showed that addition of $20 \%$ treated fiber in substitution to wheat flour produced cookies with good acceptance among the consumers. About $86 \%$ of panelists reported to like very 
much (degree 9) or a lot (degree 8) the cookies produced with treated oat hulls (Figure 1) and the acceptance index was of $91 \%$. Undesirable textures were not found in the cookies with treated fiber according to panelists, possibly due to the treatment undertaken by the hulls.

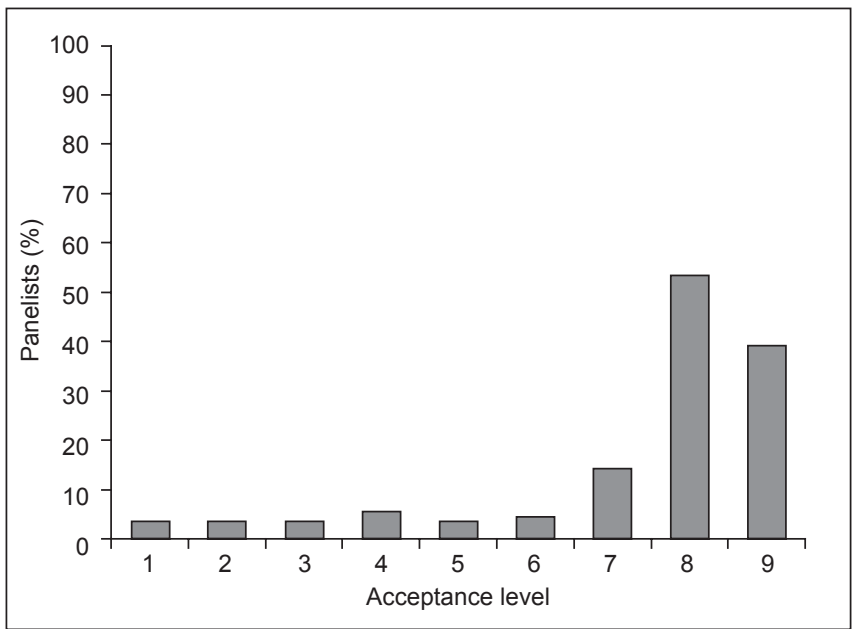

FIGURE 1 - Cookie acceptance level produced with modified oat hulls

$1=$ displeased very much; $9=$ liked very much

\section{4 - CONCLUSIONS}

The results showed that the oat hulls modified by treatment with alkaline hydrogen peroxide associated with extrusion can be used in the preparation of cookies, in moderate level (substitution of $20 \%$ of the wheat flour), without modification of physical properties and damage of sensory quality of product (91\% acceptance level). The gritty sensation of the oat hulls was eliminated after treatment showing that the destructuring of the fiber was enough to make this material sensorially acceptable. These cookies can be used in special diets when supplementation with fiber is recommended. A portion of $100 \mathrm{~g}$ of the product would supply $43 \%$ of the total recommended daily ingestion (25 g).

\section{5 - REFERENCES}

[1] AMERICAN ASSOCIATION OF CERAL CHEMISTS. Approved Methods of the American Association of Cereal Chemists. AACC. St. Paul MN, 1990.

[2] ANVISA. Portaria SVS/MS, n.41, Jan 14, In: <http:// www.anvisa.gov.br/legis/portarias/ 41_98.htm>. Accessed in Feb 10, 1998.

[3] ARTZ, W.; WARREN, C.; MOHRING, A.; VILLOTA, R. Incorporation of corn fiber into sugar snap cookies, Cereal Chemistry, v.67, p.303-305, 1990.

[4] CAMPBELL, L.A.; KETELSEN, S.M.; ANTENUCCI, R.N. Formulating oatmeal cookies with calorie-sparing ingredients, Food Technology, v.48, p.98-105, 1994.
[5] DUTCOSKY, S.D. Análise sensorial de alimentos, Curitiba: Champagnat, 1996.

[6] GALDEANO, M.C.; GROSSMANN, M.V.E. Effect of treatment with alkaline hydrogen peroxide associated with extrusion on color and hydration properties of oat hulls, Brazilian Archives of Biology and Technology, v.48, n.1, p. 63-72, 2005.

[7] GOULD, J.M.; JASBERG, B.K.; DEXTER, L.B.; HSU, J.T.; LEWIS, S.M.; FAHEY, G.C. High-fiber, noncaloric flour substitute for baked foods. Properties of alkaline peroxide-treated lignocellulose, Cereal Chemistry, v.66, p. 201-205, 1989.

[8] INGLETT, G.E. Dietary fiber gels for preparing calorie reduced foods, U.S. Patent application serial number 08/563,834, November 28, 1995.

[9] LARREA, M.A.; GROSSMANN, M.V.E.; BELEIA, A.P. Changes in water absorption and swollen volume in extruded alkaline peroxide pretreated rice hulls, Cereal Chemistry, v.74, p.98-101, 1997.

[10] LEELAVATHI, K.; RAO, H. Development of high fibre biscuits using wheat bran, Journal Food Science Technology, v.30, p. 187-190, 1993.

[11] LUE, S.; HSIEH, F.; HUFF, H.E. Extrusion cooking of corn meal and sugar beet fiber: effects on expansion properties, starch gelatinization, and dietary fiber content, Cereal Chemistry, v.68, p. 227-234, 1991.

[12] PARK, H.; SEIB, P.A.; CHUNG, O.K. Fortifying bread with a mixture of wheat and psyllium husk fiber plus three antioxidants, Cereal Chemistry, v.74, p. 207$211,1997$.

[13] RASCO, B.A.; RUBENTHATER, G.; BORHAN, M.; DONG, F.M. Banking properties of bread and cookies incorporation distillers or brewers grain from wheat or barley, Journal of Food Science, v.55, p. 424-429, 1990.

[14] ROBERTSON, J.A. Application of plant-based byproducts as fiber supplements in processed foods, Recent Res. Development in Agriculture \& Food Chemistry, v.2, p. 705-717, 1998.

[15] SANCHEZ, C.; KLOPFENSTEIN, C.F.; WALKER, C.E. Use of carbohydrate-based fat substitutes and emulsifying agents in reduced-fat shortbread cookies, Cereal Chemistry, v.72, p. 5-29, 1995.

[16] STEPHEN, M. A.; DAHL, W.J.; JOHNS, D.M.; ENGLYST, H.N. Effect of oat hull fiber on human colonic function and serum lipids, Cereal Chemistry, v.74, n.4, p. 379-383, 1997.

[17] SILVA, M.R.; SILVA, M.A.P.; CHANG, Y.K. Utilização da farinha de jatobá (Hymenaea stigonocarpa Mart.) na elaboração de biscoitos tipo cookies e avaliação de aceitação por testes sensoriais afetivos univariados e multivariados, Ciência Tecnologia de Alimentos, v. 18, p. 25-34, 1998.

[18] ZHANG, D.; MOORE, W.R.; DOEHLERT, D.C. Effects of oat grain hydrothermal treatments on wheat-oat flour dough properties and breadbanking quality, Cereal Chemistry, v.75, p. 602-605, 1998. 